\title{
Enea Silvio Piccolomini cosmógrafo
}

Cássio da Silva Fernandes*

Resumo: A obra de Enea Silvio Piccolomini (1405-1464) constitui-se num significativo exemplo da literatura humanística na Itália central no Quattrocento. Poeta, cosmógrafo, orador exímio, político, teórico do Estado, diplomata, Piccolomini seguiu a carreira religiosa e foi eleito Papa Pio II, em 1458. Personagem-chave no centro dos acontecimentos literários e políticos de sua época, Pio II esteve à frente de um pontificado marcado pela marcha dos turcos em direção ao Ocidente. Do ponto de encontro entre as tarefas do cosmógrafo, do historiógrafo e do narrador viajante, surgem seus livros que aqui nos interessam de perto: Germânia e Historia rerum ubique gestarum, este último dividido em duas obras idealizadas como pendant: Europa e Descrição da Ásia. No primeiro caso, trata-se da exposição das belezas das cidades situadas na Germânia, numa narrativa que abrange desde descrições topográficas e geográficas até a apreciação do aspecto das cidades. No segundo caso, concentrando-nos na Descrição da Ásia, buscaremos perceber como um dos principais exemplos da descrição cosmográfica humanista no Renascimento teve entre seus principais objetivos compreender os limites históricos entre dois mundos: a Cristandade Latina e o Médio Oriente. Palavras-chave: Enea Silvio Piccolomini. Papa Pio II. Humanismo. Renascimento. Cosmografia.

\section{Introdução}

Quando, em 1458, o humanista nascido em Corsignano (atual Pienza, Província de Siena), Enea Silvio Piccolomini, foi eleito Papa, sob o nome Pio II, sua obra literária era já volumosa e significativa. Autor de escritos históricos, teórico do Estado, cosmógrafo,

* Professor Adjunto do Departamento de História da Arte da Universidade Federal de São Paulo (UNIFESP), onde ensina História da Arte e da Civilização do Renascimento. Financiamento: CNPq. E-mail: cassiofer@hotmail.com. 
Piccolomini também enveredara no universo da comédia e da poesia, além de ter escrito uma novela amorosa, História de dois amantes (PICCOLOMINI, 1991). Ampla foi também sua ação política no contexto de sua época. Antes de assumir o papado, havia ocupado importantes cargos de secretário de bispos e cardeais, fora secretário da Chancelaria Imperial de Frederico III e vivera em várias partes da Europa. Atuante personagem na política conciliar, Piccolomini participa ativamente do Concílio de Basileia, em que respira a atmosfera hostil ao Papa Eugênio IV. (GARIN, 1996, p. 17). Ingressa apenas tardiamente na carreira eclesiástica, sendo nomeado Cardeal em 1456 e, dois anos depois, Papa. O papel de Piccolomini na história de seu tempo e a riqueza controversa de seu caráter permitiram a Jacob Burckhardt concebê-lo, no conjunto de seu estudo sobre o Renascimento na Itália, como figura central. $\mathrm{Na}$ ampla pesquisa para a elaboração do livro de 1860, $A$ Cultura do Renascimento na Itália (BURCKHARDT, 1978), Enea Silvio é definido como "personagem predileto" (liebling) e assume na obra o lugar reservado aos "homens extraordinários" do século XV. Este aspecto foi notado por Maurizio Ghelardi em seu livro (GHELARDI, 1991) sobre o percurso de Burckhardt na preparação da Cultura do Renascimento. Como afirma Ghelardi, precisamente

\begin{abstract}
[...] o tema humanístico da 'varietas' do mundo e da vida, que se manifesta [na obra de Piccolomini] no apoderar-se ávido das diferenças, através de um olhar que transcorre da análise dos costumes e da vida dos povos à descrição do mundo e da variedade, é onde Burckhardt, acima de tudo, dirige sua atenção (GHELARDI, 1991, p. 98).
\end{abstract}

Entretanto, a imagem do humanista tornado Papa como exemplo do conceito de nomo universale, tão importante para a compreensão burckhardtiana da natureza vigorosa e versátil do indivíduo no Renascimento, deveu muito especialmente a um livro de Piccolomini. Em seguida à assunção ao Pontificado, Enea Silvio debruça-se sobre o empreendimento literário de conceber sua autobiografia, à qual intitulou Commentarii (PICCOLOMINI, 1997). Os Commentari assumem o caráter de uma exposição ampla 
e diversificada do mundo exterior, concebido como cenário, no interior do qual se realiza o movimento vivaz do homem na terra. Assim, a descrição do ambiente natural, próprio do impulso de cosmógrafo, presente como um traço de continuidade na obra de Pio II, funciona como apresentação do cenário onde a ação do homem irá se desenvolver. A autobiografia de Piccolomini, na verdade, surge de uma intrincada tessitura literária em que a narrativa da própria vida conecta-se a uma apresentação colorida da história de seu tempo. Ao descrever, em forma de comentários e em terceira pessoa, os principais acontecimentos de sua vida, Enea Silvio concebe, ao mesmo tempo, grandes cenas históricas de sua época, nas quais ele próprio aparece no centro, como ator no cenário da história. Sua narrativa inicia-se com a descrição do ambiente natural em que a ação irá se desenvolver. Em seguida, o cenário humano é concebido. Então, ele descreve a variedade do mundo construído pelos homens: as cidades, os costumes, as migrações populacionais, a ação dos governantes, as batalhas, e tudo isso com as cores de um narrador vibrante, pleno da erudição dos historiógrafos e geógrafos antigos, douto em história natural, conhecedor da ocupação dos territórios. E, no interior dessa narrativa, aparecem os homens, descritos em esboços biográficos, contracenando com o próprio autor, o autobiógrafo. O resultado dessa construção literária é que o autor-protagonista se transforma também em sujeito da história. Como afirmou Marziano Guglielminetti em sua obra sobre a autobiografia de Dante a Celini, nos Commentari de Pio II, "[...] a autobiografia se resolve em historiografia, sem porém anular-se nela"1 (GUGLIELMINETTI, 1977 , p. 210). Este fenômeno, no entanto, foi possível a Pio II decerto por seu conhecimento de determinados modelos literários antigos; também por seu reconhecido talento como escritor, expresso ainda pela fama conquistada com a eloquente oratória. Entretanto, um motivo pode ainda iluminar o entendimento dessa intrincada solução literária apresentada nos Commentari, qual seja, o significado de sua personalidade na história de seu tempo.

De fato, o Pontificado de Pio II teve como dado histórico central a marcha do Império Turco otomano em direção ao Ocidente, após a tomada de Constantinopla. Deter os turcos era, portanto, 
tarefa primordial de seu papado no campo da ação prática, e se apresentava de modo complementar ao dramático esforço para manter a construção medieval da unidade da Igreja, malgrado os evidentes sinais de que essa mesma unidade estava já desfeita. Essa dupla tarefa aparece claramente no tecido literário dos Commentari, num esforço que congregava sua atuação como Papa e como humanista.

É nesse contexto que advém o seu projeto de escrever uma Historia rerum ubique gestarum, que ficou também conhecida como Cosmographia. Trata-se de uma história e geografia universal, da qual ele conseguirá concluir apenas duas partes: a Europa e a Descrição da Ásia. Essa obra, no entanto, ainda que inacabada, é representativa do esforço de Piccolomini em construir uma cosmografia universal. Aqui, trataremos apenas da Descrição da Ásia, livro que interessou vivamente a Cristóvão Colombo, que o leu com vagar, fazendo uma série de anotações manuscritas à margem. Utilizamos exatamente a edição anotada por Colombo, publicada na Espanha em 1992, a partir do exemplar conservado na Biblioteca Colombina de Sevilha. (PICCOLOMINI, 1992)

Através de uma passagem nos Commentari, sabe-se com certa exatidão o contexto em que Piccolomini compõe a Descrição da Ásia. De acordo com sua autobiografia, era julho de 1461 e o Pontífice seguia de Roma para Tivoli, em companhia do erudito condottiere e duque de Urbino, Federico da Montefeltro. Enquanto conversavam sobre as batalhas na Antiguidade e sobre as descrições das mesmas pelos escritores antigos, afirma Pio II, sempre utilizando o recurso da narrativa em terceira pessoa:

Passaram a falar da Ásia Menor e não chegaram a um acordo sobre seus limites. Em seguida, o Papa, quando em Tívoli teve um pouco de tempo, descreveu a Ásia reportando-se a Ptolomeu, Estrabão, Plínio, Quinto Cúrcio, Júlio Solino, Pompônio Mela e a outros antigos autores, tomando de cada um todas as notícias que lhes pareceram úteis para o conhecimento daquelas terras. (PICCOLOMINI, 1997, p. 314) 
Através desse fragmento, fica claro que a cosmografia da Ásia foi escrita em 1461, então ao mesmo tempo em que o Papa compunha os Commentari. Mas o ano de 1461 é ainda marcado por um acontecimento único na história das relações entre Ocidente e Oriente. Entre junho e agosto, as tropas turcas tomam as cidades de Sínope e Trebizonda, as últimas duas capitais gregas sob o domínio grego, que se encontram no norte da Anatólia, na costa do Mar Negro. Era o fim do mundo grego livre. As ilhas e os portos do Mar Egeu e do Mar Jônico governadas por cristãos tinham, no entanto, o controle de mãos estrangeiras. Apenas entre as montanhas do sudoeste do Peloponeso, onde nenhum turco tinha ousado penetrar, permaneceu uma aparência de liberdade. Para o Papa Piccolomini, em particular a queda de Trebizonda tinha um sabor amargo, visto que esta é a cidade natal de seu amigo e aliado, o cardeal grego de Niceia, Giovanni Bessarione. Defensor da aliança entre a Igreja bizantina e romana como modo de derrotar o Império Turco, Bessarione concebia a possibilidade de salvação e restauração do poder de Bizâncio através da fusão entre o conhecimento grego e o humanismo italiano (RUNCIMAN, 2002, p. 30). Derrotado em discussões internas à Igreja bizantina, transferira-se para a Itália nos anos anteriores à conquista de Constantinopla, tornando-se um dos principais interlocutores de Enea Silvio, seu aliado na ideia de integração entre as culturas grega e latina.

Os acontecimentos de 1461 foram, de fato, um golpe muito forte no âmago do Papa humanista que já em 1453, então secretário do Imperador Frederico III, tinha acrescentado uma nota de dor pessoal, declarando que a tomada de Constantinopla por parte dos Turcos representava "a segunda morte de Homero e Platão". (Apud RUNCIMAN, 2002, p. 143 - PICCOLOMINI, Opera Omnia, p. 716-717.)

No outono de 1461, portanto logo depois da tomada de Sínope e Trebizonda por parte do Sultão turco, Maomé II, o Conquistador de Constantinopla, Pio II escreve-lhe uma epístola, com a qual o convida a converter-se ao Cristianismo. Em troca, o Papa oferece ao sultão reconhecer o seu poder como legítima autoridade imperial. (D’ASCIA, 2001, p. 13) Numa das partes da longa epístola, Pio II exorta o sultão à conversão com as seguintes palavras: 
Toma o batismo de Cristo e o lavacro do Espírito Santo. Abraça o sacro santo evangelho e confia inteiramente nele. Assim ganharás a salvação de tua alma, assim proverás o bem do povo turco, assim poderão ser satisfeitas as tuas aspirações, assim o teu nome será celebrado ao longo dos séculos, assim a Grécia, a Itália, a Europa inteira te admirarão, assim te celebrarão a literatura grega, latina, hebraica e todas as exóticas literaturas bárbaras, assim nenhuma época silenciará os louvores a ti, assim serás aclamado artífice da paz e da vida, assim os Turcos te chamarão salvador de suas almas: os Cristãos, defensor de suas vidas; os Sírios, os Egípcios, os Líbios, os Árabes e todos os outros povos que permanecem fora do redil de Cristo, ouvindo essas notícias, seguirão o teu exemplo e serão facilmente domados por tuas armas e por aquelas dos cristãos. (D’ASCIA, 2001, p. 232)

A epístola jamais foi expedida e dois anos depois, Pio II abandona a tentativa de concórdia e decreta a Cruzada contra os Turcos, isto é, a fracassada expedição que termina em Ancona, com a morte do Papa em agosto de 1464, enquanto esperava inutilmente a chegada da frota veneziana. (D’ASCIA, 2001, p. 144)

Por outro lado, não se pode subestimar as possíveis motivações políticas internas ao mundo italiano, que poderiam ter levado Pio II a escrever a longa epístola. Na introdução à edição italiana da carta do Papa ao sultão, Luca d'Ascia sublinha a importância de tais motivações. D'Ascia refere-se às manifestações esporádicas de turcofilia que tinham em comum o reconhecimento de Maomé II como "verdadeiro" Imperador do Ocidente. A tomada de Constantinopla continha, de fato, para o soberano turco a hipótese do direito à herança dos Paleólogos. Esta herança implicava também uma forma de direito sobre o Ocidente e, em particular, sobre a Itália, além do duplo título: pela origem "troiana" (então, asiática e "turca") dos romanos e pela continuidade entre o Império Romano e o Império Bizantino. Para os governantes italianos, como Sigismondo Malatesta e, mais tarde, os aragoneses de Nápoles, que se encontravam em conflito com a Igreja, o mito imperial podia justificar a aliança com um "grande senhor" inimigo do clero. (D’ASCIA, 2001, p. 129-130) 
Piccolomini, nos Commentari, tinha já demonstrado o interesse de Sigismondo Malatesta numa aliança com os Turcos, contra a Igreja de Roma. O Papa tinha imposto contra Malatesta a excomunhão e fizera pintar o seu retrato em Roma como um monumento à ignomínia, no qual, sob a imagem do Senhor de Rimini podia-se ler: "Io sono Sigismondo Malatesta, nemico della Chiesa" (Eu sou Sigismondo Malatesta, inimigo da Igreja). Assim escreveu Pio II nos Commentari:

Sigismondo, de fato, fonte de toda malícia, alma venenosa, sem religião, sem fé, sem Deus, de nenhum pecado liberto, pouco depois (como já dissemos) foi acusado de heresia e condenado: a sua efígie foi publicamente queimada em dois lugares, diante da escadaria de São Pedro e no Campo dei Fiori, porque foi provado que não acreditava na vida futura, e afirmava, com língua obstinada e arrogante, que a alma perece com o corpo. (PICCOLOMINI, 1997, p. 453)

Para o caso dos governantes aragoneses de Nápoles, no comentário XXXI, livro V, dos Commentari, Piccolomini censurava os empreendimentos de Fernando de Aragão na Puglia. (PICCOLOMINI, 1997, p. 323) De todo modo, Pio II, com uma agudeza interpretativa adquirida sobretudo com a leitura dos historiógrafos latinos antigos (e para o caso da escrita da história recente, o grande modelo era Júlio César), com a sua acurada percepção dos interesses concretos, estava em condições de compreender o grave contexto. Era, portanto, dramático para a Igreja Romana e para a história da Cristandade Latina o momento em que Piccolomini põe-se a descrever a Ásia.

Do ponto de vista dos modelos literários antigos e do método narrativo apresentado por Piccolomini, malgrado as menções a um grande número de autores ao longo do livro, em geral os comentadores afirmam que o maior inspirador é Estrabão, escritor grego que viveu em Roma durante o império de Augusto. Ativo no século I a.C., Estrabão, após empreender viagens pelo Egito, através do rio Nilo até a fronteira da Etiópia, pela Ásia Menor, pela Itália e pela Grécia, escreveu a Geografia, em 17 livros. (BIRASCHI; SALMERI, 
2000) A Geografia de Estrabão compreendia todo o mundo conhecido: a Europa, as regiões setentrionais da África e o Egito, a Ásia até a Índia e o Ceilão, fornecendo um conhecimento de geografia, tanto natural quanto humana.

Além disso, é sabido que no final do século XIV aportava ao mundo cristão latino, junto a numerosos outros textos antigos trazidos pelos refugiados de Bizâncio já sob ameaça otomana, a Geographia de Ptolomeu. Esta obra, composta por oito livros, apresentava ainda, como apêndice, 28 cartas geográficas elaboradas por Marino de Tiro, que juntas abarcavam, numa projeção em malhas retangulares, um panorama geográfico universal. Foi grande a popularização da Geographia, de Ptolomeu, no século XV. $\mathrm{O}$ astrônomo alexandrino do século II d. C. é o primeiro nome da lista de autores antigos citados por Enea Silvio no fragmento dos Commentari, anteriormente citado, em que o Papa revela o contexto de elaboração da Descrição da Ásia.

Porém, a Historia rerum ubique gestarum, composta pelos livros Ásia e Europa, não era a primeira obra de Piccolomini de temática histórico-geográfica. Um significativo aceno no sentido de seu interesse nesse campo do conhecimento humanístico tinha surgido antes de seu projeto de composição de uma cosmografia universal. Trata-se da descrição da Germânia, que aparece, no contexto da obra de Enea Silvio, a partir de um acontecimento muito preciso. Após cerca de um mês de sua nomeação a Cardeal, ocorrida em dezembro de 1456, Piccolomini recebe uma carta de Martino Meyr, chanceler do Arcebispo de Mayença. Na carta, Meyr, em tom confidencial e ameaçador, o informava do descontentamento dos germânicos com a Cúria Romana. ${ }^{2}$ (PICCOLOMINI, 1949). Meyr acusava a Cúria de não respeitar os decretos dos concílios de Constança e de Basileia e de lançar aos príncipes germânicos uma pesada cobrança de impostos. Roma, então, era responsável, segundo o chanceler, por reduzir a Germânia, no passado senhora do mundo, à condição de miséria e de escravidão. Piccolomini sabia muito bem não apenas das condições político-eclesiásticas da Germânia de então, mas também era conhecedor de sua formação histórica, bem como da realidade da vida dos germânicos de sua época. Desde 1442, quando entrara a serviço do Imperador Frederico III, até a nomeação a Cardeal, ele tinha tido contato com príncipes laicos e com eclesiásticos da 
Germânia. Acrescente-se a isso o fato de Piccolomini, durante esses anos, ter vivido em várias cidades germânicas e, portanto, possuir um conhecimento direto, e em detalhe, das coisas dali. Na verdade, suas estadias ao norte dos Alpes remontam à década de $1430 .^{3}$

De todo modo, a resposta de Piccolomini à carta do Cardeal Meyr aparece tempos depois, em forma de um tratado dividido em três partes, intitulado De situ, ritu, moribus et conditione Germania descriptio. A terceira parte, que aqui nos interessa, foi publicada na Itália em 1949, em versão bilíngue, latim e italiano, traduzida e organizada por Gioacchino Paparelli, sob o título La Germania. (PICCOLOMINI, 1949)

A Germânia de Piccolomini surge como ponto de encontro entre as tarefas do cosmógrafo, do historiógrafo e do narrador viajante. Trata-se da exposição das belezas das cidades situadas na Germânia, numa narrativa que abrange desde descrições topográficas e geográficas, até a apreciação do aspecto das cidades, de seu traçado urbano, de suas belezas arquitetônicas, dos costumes dos habitantes, sem silenciar a respeito da ocupação do território e até da ação de ilustres personagens no campo da política, no universo eclesiástico ou na arte da guerra. Como modelo literário antigo, a Germânia, de Tácito, é referida várias vezes ao longo do tratado de Enea Silvio, embora não apenas para corroborar uma afirmação sua, mas também como posição oposta, no sentido de afirmar as diferenças entre a Germânia antiga e aquela moderna. Longe de entrar em polêmicas com os autores antigos, Piccolomini, porém, afastava-se de qualquer tipo de indeterminação abstrata, bem como não se confinava na erudição livresca. O autor, então, descreve a Germânia que teve oportunidade de observar com os próprios olhos no curso de uma permanência longa e nômade naquele território. $\mathrm{E}$ mesmo onde a referência histórica intervém para sustentar o colorido da direta descrição geográfica, ela jamais se faz de modo abstrato, como postura fundamentalmente erudita, mas sim calcada em seu espírito viajante, estimulada por uma inata curiosidade de observador, como afirma Giovanni Paparelli na introdução da edição italiana. (PAPARELLI, 1949, p. 14).

Assim, após o início, em que descreve a extensão da Germânia, Enea Silvio concentra-se na descrição de suas principais cidades, tendo como base a ideia de beleza. Ouçamos, então, a sua voz: 
Quanto à beleza do país, quem não sabe que ela é hoje maior do que em tempos atrás? Por toda parte, campos cultivados, vinhedos, jardins, canteiros, fruteiras, casas de campo e de subúrbio plenas de toda delícia, cidades esplêndidas em sua maior parte margeadas por grandes rios ou circundadas por longuíssimos canais atravessados por pontes de pedra ou de madeira. [...] O que se pode encontrar de mais magnífico e mais esplêndido em toda a Europa do que Colônia [...]? Nobre é pelas igrejas e pelos edifícios, insigne por sua população, famosa pelas riquezas, característica por seus tetos de chumbo, adornada de palácios, defendida por torres, sorridente pelo rio Reno e pelos férteis campos circundantes. (PICCOLOMINI, 1949, p. 39).

Como se pode verificar, tudo é relatado como num sobrevoo rasante, detendo-se, entretanto, em determinados pontos, para descrever com vagar os dados principais que compõem e embelezam as cidades. Esta forma de descrição vai de encontro à figura do narrador-viajante, que se fazia presente na literatura toscana desde o século XIV, como se observa no longo poema de Fazio delli Uberti (1305 ou 1309-1367), Il Dittamondo (UBERTI, 2007). Pelo trecho de Piccolomini anteriormente citado, em que relata as belezas da cidade de Colônia e do campo que integra o seu entorno, percebe-se latente o futuro autor da cosmografia universal. Mas o trecho anterior remete-nos ainda a outro escritor do Trecento toscano. Talvez tenha sido Petrarca o primeiro a fornecer, com base num agudo interesse pelas construções humanas, descrições das cidades que visitava. Cem anos antes, em 1358, Petrarca visita Gênova e a descreve nas seguintes palavras: "Verás uma cidade real encostada a uma colina alpina, soberba pela quantidade de homens e de muros, cujo aspecto basta para apontá-la como senhora do mar" (PETRARCA, 1984, p. 148.). De Petrarca em diante, são inúmeros os casos de descrição de cidades em forma de elogio. Lembremos, apenas de passagem, o caso dos elogios de Florença por Coluccio Salutati, na Invectiva in Antonium Luschum Vicentinum (Invectiva contra Antonio Loschi de Vicenza) (SALUTATI, 1976), em 1403, e a Laudatio (BRUNI, 2000), de seu discípulo, Leonardo Bruni (1430). 
Além disso, do trecho de Enea Silvio anteriormente citado, pode-se deduzir ainda o sentido que o impulsionará, logo após a assunção ao Pontificado, a reconstruir sua pequena cidade natal, Corsignano. Em 1458, ano da posse de Pio II ao Pontificado, Corsignano aparecia no panorama da Toscana como um castelo conhecido pela tradicional hospedagem a grupos de peregrinos. Já Boccaccio, na quarta novela da IX Giornata do Decamerão, refere-se ao castelo de Corsignano como um refúgio de emergência utilizado por Cecco Angiolieri e por seu companheiro de viagem no conturbado caminho em direção a Ancona. (BOCCACCIO, 2004, p. 761-765). Porém, em maio de 1459, Pio II dá início ao projeto de reconstrução de sua cidade natal, com vistas a elevá-la a sede de bispado. O projeto urbanístico é encomendado ao arquiteto Bernardo Rosselino. A parte essencial da obra é finalizada em 1462, e a cidade passa e se chamar Pienza (cidade de Pio). Pienza surgira, então, como a aplicação efetiva do conceito de "cidade ideal". O projeto de Pienza integrava a reestruturação de suas edificações e de seu traçado urbano, numa forma de fundir a dignidade pessoal do cidadão ilustre tornado Papa com a construção da dignidade de sua cidade natal. Nesse processo, o sentido da beleza fundia-se à noção de civilização, para conceber a cidade como lugar do convívio e como cenário da ação do homem, efetivo artífice do mundo que o circunda.

Este ideal certamente norteou o interesse de Piccolomini ao descrever as cidades da Germânia. O amplo panorama descritivo da região, que começara pela apresentação da extensão do território e de sua conformação física, deslocava-se gradativamente para uma interpretação muito próxima daquilo que, no mundo contemporâneo, ficaria conhecido como geografia humana. O domínio da natureza desembocava, então, na maior construção do homem: a cidade. Construção ideal da ordenação do convívio humano, a cidade aparece ainda como organização político-jurídica, como palco do desenrolar da vita civile. Então, Enea Silvio detém-se na explanação sobre o governo das cidades e sobre o caráter de seus governantes na Germânia, para, em seguida, concentrar-se em descrever os cidadãos ilustres. E dentre as principais ações do personagem ilustre está o próprio embelezamento da cidade, processo contínuo e infindável, reflexo da cotidiana tarefa de autoconstrução humana. Então, a descrição das cidades, na 
Germânia, de Piccolomini, desagua numa exposição da beleza das artes, sob a visão de um viajante erudito e refinado apreciador dos artifícios da civilização. Assim, a catedral de Estrasburgo, "magnífico edifício em pedra [...], adornado de duas torres, das quais a única finalizada se eleva até as nuvens" (PICCOLOMINI, 1949, p. 43). Assim, a cidade de Aachen, "[...] onde o mais famoso palácio de toda a Germânia faz mostra de apreciáveis estátuas em pedra de vários imperadores germânicos" (PICCOLOMINI, 1949, p. 43). Assim, a capital da Boêmia, Praga, "[...] grandíssima e belíssima cidade, não menor, nem diversa de Florença, mas atravessada por um rio de nome Moldava, muito maior do que o Arno" (PICCOLOMINI, 1949, p. 51).

O elemento primordial da descrição de Piccolomini é o espaço. Inicialmente o espaço entendido como extensão geográfica; em seguida, o espaço como constructo humano, como produto da virtù que dignifica determinados homens, que os eleva à condição de viri clari, de uomini illustri. A esses, a narrativa de Piccolomini detém-se a esboçar a biografia, às vezes quase ao nível da descrição de um retrato. Vejamos o exemplo do encômio ao Rei Alberto de Brandenburgo:

Não sabemos de ninguém que possa ser colocado acima dele ou ao seu lado. E, de fato, não apenas neste homem refulgem de modo singular os dotes militares e as virtudes de condottiero, mas também se tornam nele admiráveis a nobreza de sangue, a alta estatura, a beleza do rosto, a elegância do falar e a força física. (PICCOLOMINI, 1949, p. 87-89).

Portanto, este é um caso típico em que a descrição do personagem integra desde sua virtude como cidadão até sua postura e seu aspecto físico, numa estreita relação com o interesse pela arte do retrato, enormemente cultivada na Itália do século XV.

Assim, a descrição da Germânia apresenta vários elementos da narrativa cosmográfica que, imediatamente depois, ganhará forma universal na concepção de dois livros: Europa e Ásia. Entretanto, já na Germânia, a noção de espaço é a base da narrativa histórica. O espaço, inicialmente pensado como extensão de terra, como geografia física, ganha, no transcorrer do texto, a conotação de espaço construído pela intervenção humana. Então, a geografia passa a ser 
espaço da ação do homem: transforma-se, com isso, em geografia humana, para utilizar um termo atual. É aí que a cidade aparece como artifício e como célula em que se desenvolve a vida. Dessa forma, Piccolomini observa a história como prática do viajante refinado, em que a observação é o dado primordial. Assim, a história ganha o caráter de uma ampla visão do cosmo, em que cintila a imagem do homem em movimento no meio do mundo. Eugenio Garin, num ensaio sobre Piccolomini, definiu com as seguintes palavras a consideração do mundo por parte do humanista de Siena na descrição da Germânia:

[Piccolomini] tinha nascido 'geógrafo', no sentido mais rico do termo: curioso pelo encontro entre o homem e a terra, pelo vínculo entre a história e o seu ambiente, entre as cidades e os habitantes, entre os lugares e a vida que ali se desenvolve. [...] Mas a terra transformou-se através de tanta história. E os povos, as guerras, as migrações, as cidades construídas e destruídas, os costumes, tudo converge na visão deste nosso mundo em processo: historia rerum ubique gestarum locorumque descriptio. (GARIN, 1996, p. 19-20).

Enea Silvio retoma este modelo narrativo anos depois, quando da composição de sua história e geografia universal. A Descrição da Ásia apresenta um vivo interesse geográfico, voltado, sobretudo, aos assentamentos e às estruturas dos grupos humanos, abarcando a história remota dos povos e compondo um amplo balanço de países, costumes e das construções do homem. Sua erudição humanística alia-se ainda ao gosto pela paisagem, ao encanto pela doçura da natureza, a uma cativante curiosidade pelo exótico e pelo diferente. Seu cenário possui uma amplitude extraordinária: ele descreve a topografia, com atenção aos rios, aos montes, às planícies, discorre sobre os territórios, as cidades, as migrações dos povos, os cultos e as religiões, até concentrar-se em acontecimentos importantes como guerras e ascensões dinásticas. Nesse particular, por intermédio dos autores antigos, Piccolomini interessa-se primordialmente pela atuação dos imperadores romanos entre os mais distintos povos da Ásia. Ele ainda descreve o panorama dos 
traçados urbanos, as construções arquitetônicas, os objetos confeccionados pela mão do homem, para, então, dedicar-se aos próprios homens, narrando episódios das vidas de homens ilustres que deixaram suas marcas no território asiático. E, como na Germânia, tudo é relatado como num sobrevoo, detendo-se, entretanto, em determinados pontos, para descrever com vagar os dados principais de cada uma das seis partes em que ele divide a Ásia. Tudo é descrito, portanto, na forma típica do livro de viagem, mesmo sem jamais ter estado na Ásia. E, nesse particular, vale ressaltar que em meio aos relatos dos cosmógrafos antigos, Piccolomini insere as descrições de viajantes tardo-medievais, sobretudo de um certo Niccolò di Venezia. É, de fato, significativo que o arranjo narrativo da Descrição da Ásia assemelhe-se àquela dos Commentari, ainda que no primeiro caso se trate de uma cosmografia e no segundo, de uma autobiografia. Entretanto, se na Ásia temos uma maravilhosa descrição de viagem, nos Commentari deparamo-nos com a narrativa da vida de um viajante (o próprio autor), atento aos dados cosmográficos dos territórios percorridos e a detalhes biográficos dos personagens encontrados.

Vasto, portanto, é o interesse do Pontífice cosmógrafo. Entretanto, em meio à variedade que constitui o mundo apresentado por Pio II, um propósito pode servir de amálgama, permitindo a compreensão do impulso que o levou a conceber a cosmografia da Ásia. É clara a fascinação do autor pelo Oriente, repleto de dados de interesse econômico e militar. É sabido que Piccolomini mantinha a seu lado, a pagamento, cosmógrafos especialistas no mundo oriental, como é o caso do veneziano Girolamo Bellavista. De todo modo, o propósito político que guia o seu olhar de geógrafo em direção à Ásia (sobretudo, à Ásia Menor) é o desejo de revanche contra os turcos. O próprio autor revela a razão maior que o levou a descrever a Ásia:

Tudo isso o resenhamos com mais extensão talvez que necessária [ele diz], a fim de que aqueles que o leiam entendam quanto perdeu a República Cristã, pois ela foi a razão principal que nos moveu a descrever a Ásia em suas diversas partes, descendo até o mínimo detalhe. Pode ser que alguém diga que não foi menor a perda da Grécia, tida 
por mãe de toda a ciência e plena de glórias guerreiras, ou da Síria, onde apareceu o primeiro homem e onde nasceu Cristo e redimiu pela cruz a linhagem humana, abrindo-nos o caminho do céu. (PICCOLOMINI, 1992, p. 257).

A perda a que se refere Piccolomini diz respeito, sobretudo, ao avanço do poderio otomano na Ásia Menor. O Pontífice percebe, no passado, um sentido de continuidade na relação entre Ocidente e Oriente Médio. Para ele, o Império Romano foi o elemento que permitiu certa integração entre Ocidente e Ásia Menor, tendo atuado como veículo civilizatório (ou seja, como portador daquilo que Piccolomini chama "vita civile") que se estendeu para ambas as direções. No pensamento de Enea Silvio Piccolomini transparece um apreço pelos valores culturais fundados na tradição clássica, sobre o culto de Roma e do pensamento antigo; a noção de unidade de estruturas e de tradições históricas, delimitadas num espaço geográfico, que ele buscou traçar através das linhas de uma (muitas vezes contraditória) fusão entre saber antigo e preceitos do cristianismo. De todo modo, uma fusão tecida sob o fundo da paisagem romana. Sob esta base certamente desenvolveu-se, com forte teor dramático, sua descrição da Ásia. Nesse escrito, Piccolomini observa que a tradição grega, absorvida e modificada pelo mundo latino, espraiou-se pelo Médio Oriente. O Império, então, cristianizou-se. A primeira ruptura com o Oriente próximo é, para ele, o aparecimento de Maomé e do maometismo, essa "religião criminosa" (PICCOLOMINI, 1992, p. 221), como afirma. Entretanto, há, por parte de Pio II, um respeito com relação aos sírios. Nesse caso, a ruptura com o cristianismo, por parte dos sírios, não representa exatamente o abandono da civilização. Com os sírios é possível conviver. Há, inclusive, uma amálgama civilizatória comum, dada pelo Império Romano. Porém, o grande inimigo da República Cristã e, portanto, da civilização, são os turcos.

É como se Piccolomini vivesse, em potência, uma contradição que caracterizou a cultura humanística toscana. De fato, sua formação erudita tem estreita relação com o humanismo florentino da década de 1430. Enquanto realizava os estudos jurídicos, ele empreendia apaixonadas leituras dos clássicos antigos e, em Florença, teve 
contato direto com o humanista Francesco Filelfo (1398-1481) e com o secretário da República, Poggio Bracciolini (1380-1459). O ideal republicano florentino tinha formado a consciência política de Piccolomini, e se expressava em sua postura de humanista refinado, de historiador e de escritor de temas amorosos, mas também em sua atuação política e diplomática, defensor do conciliarismo. Porém, paralelamente a isso, e sobretudo após a assunção ao Pontificado, Enea Silvio busca re-fundar as instituições universalistas (a Igreja e o Império) à luz da continuidade com a tradição antiga. Este caráter universalista esteve presente em seu posicionamento e julgamento histórico frente ao Oriente próximo. O Império Romano, entendido como unidade civilizatória, foi a base de sua compreensão da história na Descrição da Ásia, e também esteve presente no teor da longa epístola ao Sultão turco, Maomé II. Como fundamento implícito de tudo isso, cintilava o ideal imperial, a ideia de um "nuovo impero", a se plasmar sobre as feições da Roma Antiga, porém agora de caráter não temporal, mas espiritual. Um império civilizatório sob a égide de uma fusão humanística entre a Roma pagã e a Roma cristã, um império que amalgamava a aparente contradição entre as diferenças locais e a unidade da civilização. Nesse sentido, a Ásia, de Pio II, observada isoladamente, compreendia já o esboço da obra idealizada como seu pendant, a Europa.

De todo modo, é a partir dos turcos que Piccolomini constrói os limites entre Ásia e Europa, limites entre a civilização (a República Cristã) e o mundo dos infiéis. Para ele, os valores culturais fundados na tradição clássica, sobre o culto de Roma e do pensamento antigo, embebidos no sentimento de afinidade moral e espiritual com os Gregos, fundidos depois nos preceitos da Cristandade, estavam a perigo pela ameaça turca. Os Turcos, após conquistarem Constantinopla e se tornarem donos de todo o Oriente próximo, tornaram-se o "outro" por excelência, transformando a Ásia efetivamente numa individualidade distinta. E, nesse ponto, Pio II começava a entrever, sob a égide de um conjunto de valores humanos, a Europa como unidade de civilização, representada por um conjunto de doutos interessados em comentar os textos antigos, formando a "república" da inteligência e da cultura. Assim, ao descrever a Ásia, Piccolomini, começava a delinear também a identidade de Europa. 
O livro sobre a Ásia, impresso originalmente em Veneza, em 1477, chega às mãos do navegador genovês, Cristóvão Colombo, depois de seu retorno da viagem de descoberta, a viagem de 1492. É provável que o navegador tenha se ocupado da leitura da Ásia, de Pio II, em torno de 1497, quando organizara uma pequena biblioteca de livros geográficos para se certificar neles de sua façanha. Dentre os livros consultados por Colombo nessa fase estão o Milione, de Marco Polo, e a Imago mundi, de Pierre d'Ailly. De todo modo, Colombo lê com profundidade a descrição da Ásia, de Piccolomini, e faz uma série de anotações manuscritas à sua margem. A edição da cosmografia universal de Piccolomini manipulada por Colombo, é importante frisar, não continha o volume sobre a Europa, mas apenas a Descrição da Ásia. O livro, que se encaixa perfeitamente no contexto dos descobrimentos, interessou ao navegador, sobretudo, nas partes que tratam da Índia, das costas da Ásia e das regiões mais distantes e menos conhecidas da Ásia que então se tinha notícia. As notícias da Ásia no século XV, é bom recordar, davam conta de uma região muito maior do que se revelaria no futuro. Seja como for, o que chama mais a atenção de Colombo são exatamente as partes menos carregadas pela energia vital que moveu Piccolomini a escrever o livro. Assim, onde está o cerne dos problemas históricos e políticos que Piccolomini pretende tratar, então a Ásia que o humanista de Siena concebe a partir das ilhas do Mar Egeu e que compreende o chamado Oriente Médio, interessa menos ao olhar de Colombo. O mundo carregado de uma grave tensão histórica para Pio II, ou seja, as terras em torno do Mediterrâneo oriental, são as partes do livro em que o navegador genovês atravessa de modo mais ligeiro. Portanto, o problema em torno dos limites entre Europa e Ásia, limites vincados pelo perigo da ameaça turca, que se nutrira exatamente da tensão que moveu o Papa a elaborar o livro, constituem-se nos traços menos atrativos à curiosidade de Colombo.

Ao contrário, as anotações de Colombo às margens do livro aparecem de modo mais intenso em relação aos comentários geográficos de Pio II sobre os confins do mundo habitado. Quando Piccolomini, com grande erudição humanística, colhe informações de cosmógrafos antigos para delimitar até onde, no extremo oriente, foram encontrados vestígios da existência de povos, é que se levanta a voz 
de Colombo. Então, as anotações marginais do navegador dão conta de um mundo mais extenso e pleno da existência de povos. E para contrapor os autores antigos, Colombo utiliza notícias trazidas por navegadores portugueses e, às vezes, por viajantes ingleses e suevos. O genovês, então, contesta a ideia dos limites do mar navegável apresentada por Pio II, que se baseava sobre relatos de escritores antigos. Um exemplo é o trecho em que Piccolomini segue a divisão da terra em cinco partes, feita por Parmênides. Nessa passagem do texto do erudito Papa, pode-se encontrar a nota marginal de Colombo, com as seguintes palavras:

[Parmênides] considerou que as duas partes mais próximas ao pólo, por causa do frio, e uma terceira parte, que está sob a passagem do Sol, por causa do calor, são inabitáveis. O contrário se prova na parte austral pelos portugueses e na setentrional pelos ingleses e suevos, que navegam por estas partes. (PICCOLOMINI, 1992, p. 6).

Há, assim, entre a Descrição da Ásia, de Piccolomini, e as anotações ao livro, feitas por Cristóvão Colombo, uma oposição entre o conhecimento cosmográfico no início do Renascimento, trazidos pelo humanista de Siena, e o conhecimento moderno de Colombo, baseado na empiria das cartas de navegação e nos relatos de exploradores da segunda metade do século XV. Colombo, na verdade, tinha-se debruçado sistematicamente sobre as cartas de navegação e os relatos de viajantes ao Mar Oceano quando se estabeleceu em Lisboa, a partir de 1477. Em Lisboa, ao lado do irmão Bartolomeo, Cristóvão Colombo abrira um pequeno negócio, onde desenhava e vendia cartas náuticas e livros de navegação. Lisboa, portanto, tinha sido o local de contato mais estreito com as águas que conduziam ao mundo desconhecido, além de representar o período de preparação para a vida que ele abraçaria dois anos depois, na ilha de Porto Santo, ao lado da esposa, filha do governador daquela possessão de Castela.

De todo modo, entre e descrição da Ásia de Piccolomini e as anotações de Colombo às margens do livro existia uma linha divisória. De fato, uma oposição entre o saber histórico-político 
centrado no mundo mediterrânico e o interesse pelo universo aberto pelas descobertas das rotas oceânicas entre o Atlântico, o Índico e os caminhos em direção ao extremo Oriente. Piccolomini, humanista toscano do Quattrocento tornado Papa, interessa-se, sobretudo, pela diversidade de mundos que convergem para esse mar no meio das terras. Colombo, o conquistador de mundos desconhecidos, o descobridor dos caminhos que circundam o mundo por fora e que conduzem ao inconcebível, interessa-se pelo que a Ásia de Piccolomini apresenta de exótico. São as informações topográficas, as notícias de caráter geográfico e os mais fabulosos relatos de costumes o que chamam a atenção do navegador e, ainda assim, ele coteja tudo isso com os dados contemporâneos e os corrige, quando necessário.

Na Descrição da Ásia, Piccolomini apresentava a erudição geográfica antiga e a observação de navegadores e cosmógrafos venezianos como contraponto à cosmogonia medieval. Entretanto, as anotações de Cristóvão Colombo ao livro do erudito Papa traziam a experiência dos relatos das primeiras incursões ao Mar Oceano e demonstravam um interesse muito distante daquele do Pontífice cosmógrafo. As anotações de Colombo revelavam um impulso em direção aos confins da imaginação europeia do Quattrocento. Este universo que se abriria pelas caravelas dirigidas pelo navegador genovês anunciava, de fato, um novo mundo. Era uma revelação de que entre o humanista quatrocentista de Siena e o navegador-descobridor da viragem do século XV existia uma linha divisória, separando mais do que dois séculos, dois mundos.

\section{ENEA SILVIO PICCOLOMINI COSMOGRAPHER}

ABSTRACT: The work of Enea Silvio Piccolomini (1405-1464) constitutes a significant example of humanistic literature from central Italy in the Quattrocento. Poet, cosmographer, eminent orator, political theorist of State, diplomat, Piccolomini followed the religious career and was designated Pope Pius II in 1458. Protagonist in the center of the literary and political events of his time, Pius II was ahead of a pontificate marked by Turks march toward the West. The meeting point between responsibilities as cosmographer, the historian and the narrator traveler, his books that arise here concern us closely: Germania and Historia rerum ubique gestarum, the latter divided into two works idealized as 


\section{Enea Silvio Piccolomini cosmógrafo}

pendant: Europe and Description of Asia. In the first case, it is the exposure of the beauties of the cities in Germania, a narrative that ranges from topographical and geographical descriptions, to the appreciation of the appearance of cities. In the second case, focusing on the description of Asia, we will look for to realize as a most important example of the cosmographical humanistic description in the Renaissance, which one of its main objective is to understand the historical limits between two worlds: the Middle East and Latin Christianity.

KEYWORDS: Enea Silvio Piccolomini. Pope Pius II. Humanism. Renaissance. Cosmography.

\section{Notas}

${ }^{1}$ Sobre este tema, ver: TOTARO, Luigi. Pio II nei suoi "Commentarii". Bologna: Pátron Editore, 1978, em particular p. 187.

2 PAPARELLI, Gioacchino. Introduzione. PICCOLOMINI, Enea Silvio. La Germania. (A cura di Gioacchino Paparelli.) Firenze: Fussi, 1949, p. 9-14. A carta do Cardeal Martino Meyr foi publicada na mesma edição, p. 15-21.

${ }^{3}$ Provavelmente em 1434, em Estrasburgo, conheceu Isabela, com quem teve um filho, fruto de uma história de amor narrada detalhadamente a seu pai numa carta que é uma construção literária à maneira do explícito poema Hermafroditus de Antonio Beccadelli (1394-1471). BECCADELLI, Antonio. L'Hermafrodite. Traduit pour la primiere fois par Alcide Bonneau, avec le texte latin e un choix des notes de Forberg. Paris, 1892.

\section{Referências}

BECCADELLI, Antonio. L'Hermafrodite. Traduit pour la primiere fois par Alcide Bonneau, avec le texte latin e un choix des notes de Forberg. Paris, 1892.

BIRASCHI, Anna Maria; SALMERI, Giovanni (a cura). Strabone e l'Asia Minore. Napoli: Edizione Scientifique Italiane, 2000.

BOCCACCIO, Giovanni. Decameron. (A cura di Vittorio Branca) Volume Primo. Milano: Arnoldo Mondadori Editore, 2004.

BRUNI, Leonardo. Laudatio florentine urbs. (A cura di Stefano U. Baldassarri). Tavarnuzze (Firenze): Sismel, 2000.

BURCKHARDT, Jacob. Die Kultur der Renaissance in Italien. In: Gesammenlte 


\section{Cássio da Silva Fernandes}

Werke, Band III, Basel/Stuttgart: Schwabe, 1978.

D'ASCIA, Luca. Il Corano e la tiara. L'epistola a Maometto di Enea Silvio Piccolomini (Papa Pio II). Bologna: Edizioni Pedragon, 2001.

GARIN, Eugenio. Ritratto di Enea Silvio Piccolomini. In: GARIN, Eugenio. Ritratti di umanisti. Milano: Bompiani, 1996.

GHELARDI, Maurizio. La scoperta del Rinascimento. L "Età di Raffaello" di Jacob Burckhardt. Torino: Giulio Einaudi Editore, 1991.

GUGLIELMINETTI, Marziano. Memoria e scritura. L'autobiografia da Dante a Cellini. Torino: Einuadi, 1977.

PAPARELLI, Gioacchino. Introduzione. PICCOLOMINI, Enea Silvio. La Germania. (A cura di Gioacchino Paparelli.) Firenze: Fussi, 1949.

PETRARCA, Francesco. Rerum familiarum libri, XVII-XXIV (Letters on Familiar Matters, Volume 3). The Johns Hopkins University Press, 1984.

PICCOLOMINI, Enea Silvio (Papa Pio II). Descriptión de Asia. Madrid: Alianza Eitorial, 1992. . La Germania. (A cura di Gioacchino Paparelli.) Firenze: Fussi, 1949. . Storia di due amanti. 3. ed. Palermo: Sellerio Editore, 1991. . (Pio II). I Commentari. 2. ed. Siena: Edizoni Cantagalli, 1997.

RUNCIMAN, Steven. The Fall of Constantinople 1453. Cambridge University Press, 1965. Edição brasileira: A Queda de Constantinopla 1453. Rio de Janeiro: Imago Editora, 2002.

SALUTATI, Coluccio. Invectiva in Antonium Luschum Vicentinum. In: GARIN, Eugenio (a cura). Prosatori Latini del Quattrocento. Volume I. Torino: Einaudi, 1976.

TOTARO, Luigi. Pio II nei suoi “Commentarii”. Bologna: Pátron Editore, 1978.

UBERTI, Fazio degli. Il Dittamondo. A cura di Marco Prinari. Edizioni digitali del CISVA, 2007.

Recebido em: 19/11/2013.

Aprovado em: 12/03/2014. 
